\title{
THE SOUTH AFRICAN MILITARY ACADEMY'S EDUCATIONAL OFFERINGS AND THE NATIONAL THREAT PERCEPTION
}

\author{
Lt Col (Dr) Deon Visser ${ }^{1}$ \\ Subject Group Military History, \\ Faculty of Military Science, Stellenbosch University
}

\begin{abstract}
The national threat perception of a nation is an important guideline for the education of its officers, since it defines or anticipates the general military and socio-political milieu in which those officers must be prepared to operate. This paper traces the evolution of the threat perception of the South African Department of Defence since 1950 and the response of the South African Military Academy in terms of its educational programmes. It highlights the attitude of Defence Headquarters towards the Military Academy as a military-academic institution and the historical position of the Academy in the course of officer development. The paper also investigates the number and demographic profile of students routed through the Military Academy, which is central to these issues. Today, in the wake of the termination of the so-called Bush War on her borders and the liberation struggle within her frontiers, there is no clear, direct military threat against South Africa. In the absence of such a threat, the secondary functions of the SANDF, particularly regional peacekeeping and peace support operations, seem to occupy the centre stage. The paper therefore concludes with a perspective on the relevance of the Military Academy's current academic offerings to the preparation of SANDF officers for their perceived role scenario in the twenty-first century.
\end{abstract}

1. The author is indebted to colleagues Lt Cols Abel Esterhuysen and Ian van der Waag for their comments and, in the case of the latter, also for language advice. 


\section{Introduction}

Referring to Clemenceau's much-quoted statement that "war is too important to be left to generals", Carl W. Reddel points out that, 'for better or for worse' it is indeed the generals and admirals, in the final analysis, who 'look after the conduct of warfare'. He therefore concludes that 'the success of their education, training and performance is vital for the short- and long-term survival of all nations'. ${ }^{2}$ If one considers that an officer's performance is mostly determined by his/her education and training, which imparts the knowledge, skills, values and attitudes essential to his/her profession, ${ }^{3}$ then that aspect is clearly of the utmost importance. The recent US decision to go to war with Iraq was certainly a political one taken by the Bush administration, but certainly not without a substantial input from its generals and admirals. Although the rules of engagement for that war were no doubt laid down in principle by the US political authorities, the conduct of the war was in the hands of the military, not only those of the generals and admirals, but also junior officers and even non-commissioned officers and private soldiers. The performance and conduct of these officers and men were not only vital in breaking the ability and will of the Iraqi forces to resist, but also in shaping local and global public opinion on the US intervention, particularly in their ongoing efforts to establish law and order and negotiate the low-intensity conflict in which they became embroiled to pave the way for the establishment of a new, credible political dispensation.

Given this complex playing field, one can only endorse Reddel's assessment that 'public military service... [is] without question the most demanding profession' of the twenty-first century and that 'no other professional role incorporates such a wide range of decision-making challenges posing profound implications for nations and their societies - nationally, regionally, and globally'. ${ }^{4}$ Military decisions and policies today, more than ever before, have the potential for 'ethical, economic, social, and political ramifications ${ }^{15}$ far beyond the battlefield. This puts a huge premium on professional competence based on sustained intellectual development. To this end Col Don J. Snider (US Army, retired) observes:

C.W. Reddel. 1998. Preface. In E.V. Converse III (ed). Forging the Sword: Selecting, Educating, and Training Cadets and Junior Officers in the Modern World (Imprint Publications, Chicago), p xii.

3. E.V. Converse III. 1998. Introduction. In E.V. Converse III (ed). Forging the Sword: Selecting, Educating, and Training Cadets and Junior Officers in the Modern World (Imprint Publications, Chicago), p 1.

4. C.W. Reddel, Preface, p xi.

5. C.W. Reddel, Preface, $\mathrm{p}$ xi. 
The serious obligations of officership - and the enormous consequences of professional failure - establish professional competence as a moral imperative. More than knowing one's job or proficiency in the skills and abilities of the military art, professional competence in this sense includes worldly wisdom, creativity and confidence. Called to their profession and motivated to master their practice of it, officers are committed to a career of study and learning. ${ }^{6}$

Since junior officers of today are the generals of tomorrow, their education is tantamount to laying the foundation for future generalship. Flawed junior officer education may well produce flawed generalship in the longer term. In an effort to prepare officers best for their professional role, defence forces have historically studied and copied the officer development systems of other nations, resulting in many similarities and even a broad common pattern internationally. ${ }^{7}$ Though referring to US army officers specifically, Snider in fact sums up this broad pattern when he states that the 'developmental goals of all commissioned officers should be to better understand the... identities of the officer and how they... are integrated into individual practice... understanding that they are simultaneously warfigthers, leaders of character, members of a profession, and servants of the nation. ${ }^{8}$ Besides thorough, functional military preparation, this clearly calls for a broad, liberal education that will enable officers to view their socio-political environment in perspective and conduct themselves accordingly.

Yet the circumstances, values and attitudes of nations differ and consequently also their needs regarding officer development. Furthermore, the national and international position of nations changes over time, demanding a continuous review of their officer training and educational programmes. Defence forces thus have to keep track of international trends on the one hand in order to avoid lagging behind, and, on the other hand, they must timeously adapt to their own changing needs. In deciding how to train and educate officers for the complex military scenario of the 21 st century, the threat perception of a nation is obviously an important guideline, since it defines or anticipates the broad military and sociopolitical milieu in which officers must be prepared to operate. The direction taken from the threat perception must, of course, be set against the broader, fundamental goals of officer education referred to above.

7. E.V. Converse III, Introduction, pp 1, 361.

8. D. J. Snider, The Professional Practice, $\mathrm{p} 8$. 
The aim of this paper is to determine how the South African Military Academy has historically responded to the national threat perception in terms of its academic offerings. The paper traces the evolution of the South African threat perception since 1950, as reflected in the White Paper on Defence, and investigates the relevance of the Military Academy's educational programmes to the perceived threat perception. For this purpose the official threat perception is taken at face value, without any attempt at analysing its validity. The paper further explores the attitude of Defence Headquarters towards the Military Academy as a militaryacademic institution and the historical position of the Academy in the course of officer development. It also investigates the related issue of the number of students routed through the Military Academy and the demographic profile of the student body. The paper concludes with a perspective on the relevance of the Military Academy's current academic offerings to the SANDF's educational needs with a view to the contemporary threat perception and South Africa's prospective international (regional) role in the 21 st century.

\section{The Military Academy At The Dawning Of The Nuclear Age}

In the years following immediately after the Second World War South Africa's defence policy remained closely intertwined with that of Great Britain. As a member of the Commonwealth the Union accepted co-responsibility for defending the gateways of Africa, and in particular the Middle East, which was considered to be Africa's first line of defence. At a national security level South Africa faced no real threat from Africa or anywhere else. ${ }^{9}$ Consequently, when the Military Academy was established in Pretoria in 1950, its curricula was aimed generally at meeting the military-academic challenges of officer development in the high-tech environment of the nuclear age and to place the Union Defence Force on par with Western standards. ${ }^{10}$

Broadly following the West Point-model, the focus at the Academy was on the Natural Sciences. At military academies internationally, much emphasis was still being placed on Mathematics, which was regarded more suitable than the liberal arts in the cultivation of critical thought for the kind of decisions military officers would have to take. Only $25 \%$ of the annual intake at the Academy was allowed to follow the BA(Mil) course. The bulk of the cadets had to take the BSc(Mil) course.

9. Republic of South Africa. 1971. Review of Defence and Armaments Production: Period 1960 to 1970 (Defence Headquarters, Pretoria), pp 5, 9.

10. South African National Defence Force Archives (hereafter: SANDFA), CGS (War) 281, 56/36, Acting Chief of the General Staff (hereafter: CGS) - Minister of Defence, 22 March 1949; SANDFA, SA Mil Col (Gp 1) 164, MC/T/12/1, Cmdt SA Mil Col - Director Policy Coordination, 27 May 1949; SANDFA, AG(3) 222, AG(3)1906/9 Vol 1, Acting Secretary of Defence. - Minister of Defence, 5 July 1949. 
Furthermore, Mathematics, Physics and Chemistry, were compulsory even in the BA(Mil) degree. At the same time, however, a few core subjects directly relevant to the military profession, namely Military History, Military Law, Military Geography and Military Technology, were also compulsory for both degrees. The military degree courses thus had in common a distinct military-academic foundation. The emphasis on this common professional foundation is born out by the fact that these latter subjects were grouped together within the collective discipline 'Military Science'. ${ }^{11}$ This common military-academic base had some grounding in the social sciences, which was in line with the notion of a broad, liberal education ${ }^{12}$ pursued by military academies after the Second World War.

The international focus on a broad, liberal education was clearly aimed at creating an understanding of the complex socio-political milieu within which the military operates. From that perspective, the absence of Political Science as a core subject in the BSc(Mil) and BA(Mil) curricula, ${ }^{13}$ was an obvious hiatus. More serious perhaps, were two other shortcomings. Firstly, with an annual intake of a mere 30 cadets, and furthermore from only the army and air force, not all prospective officers were routed through the institution. Secondly, the Union Defence Force and its officers' corps did not accept ownership of the Military Academy. This might, partially at least, be attributed to the fact that the Academy was the brainchild of the new Nationalist Defence Minister, F.C. Erasmus, whose political motives were not shared throughout the officers' corps. Of greater significance, however, was the fact that very few serving officers had enjoyed the benefit of a university education and felt threatened by this novel development. Furthermore, the lecturing staff at the Academy, though in uniform, was recruited from civil society and had very little (if any) credibility in the eyes of the military on account of their lack of military training and experience. ${ }^{14}$ These views and attitudes hampered the development of the fledgling Academy and almost caused it to be closed down in the mid-1950s. ${ }^{15}$

11. University of Pretoria Archives, Minutes of the Council of the University of Pretoria 1950, Minutes of meeting between representatives of the University of Pretoria and the UDF, 26 May 1950 .

12. H. Thomas. 1961. The Story of Sandhurst (Weidenfeld and Nicolson, London), pp 223-31; T.J. Crackel. 1991. The Illustrated History of West Point (Harry N. Abrams Inc, New York,), pp 225, 239-43; S. Forman. 1950. West Point: A History of the United States Military Academy (Columbia University Press, New York), pp 199, 208-13, 219.

13. SANDFA, AG(3) 222, AG(3)1906/9 Vol I, Military Academy curricula, 21 July 1950.

14. M. van Niekerk - G.E. Visser, interview, Saldanha, 16 September 1992; C.M. Bakkes - G.E. Visser, interview, Pretoria, 29 July 1993; E.L. Bekker - G.E. Visser, interview, Saldanha, 24 March 1999.

15. SANDFA, CG C43 D81, CGS/GPT/1/3/1/1 Vol 3, CGS - Minister of Defence, 29 May 1954. 
Though the Academy's response to the threat perception in the early 1950s was thus reasonably satisfactory in terms of its educational programmes, it was flawed in terms of the number of officers it delivered and the value that the military attached to its academic offerings.

The Former South African Goverment's Perception Of The Cold War And The Liberation Struggle

South Africa's threat perception changed dramatically at the beginning of the 1960s. To demonstrate their departure from colonialism the Western powers had withdrawn from the African continent with great speed after World War II. The Union perceived this exodus as paving the way for communist expansion in Africa, which presented an indirect onslaught on Western capitalism to achieve the (former) Soviet Union's aim of world domination and international communism. In its threat perception the Apartheid government thus stressed the prevailing Western view that the Soviet Union, in pursuance of its aim of world domination, was supporting and exploiting dissatisfaction, insurrection and liberation struggles across the globe to expand its influence, gain footholds and strangle the Western powers. ${ }^{16}$ It therefore portrayed both the internal liberation struggle, spearheaded by the African National Congress (ANC) and the Pan Africanist Congress (PAC), and the hostility of the newly independent or self-governing African states towards South Africa as local manifestations of the global communist onslaught against the West. ${ }^{17}$ This perception was strengthened when the ANC and the PAC, banned by the Verwoerdgovernment, formed military wings (Umkhonto we Sizwe (MK) and Poqo, later succeeded by the Azanian People's Liberation Army (APLA)), and forged ties with the Soviet Union and Red China respectively to obtain support for an armed struggle against the governing powers. ${ }^{18}$

Having established bases outside the borders of the Republic of South Africa, MK and Poqo embarked upon a campaign of low-intensity armed resistance against the Apartheid state in the early 1960s. ${ }^{19}$ By the late 1960s an externally based unconventional guerrilla onslaught against the state was also materialising. In

16. Republic of South Africa, Review of Defence and Armaments Production: Period 1960 to 1970, pp 5, 9; Republic of South Africa. 1975. White Paper on Defence and Armament Production, 1975, p 7; Republic of South Africa. 1982. White Paper on Defence and Armaments Supply, 1982, p 1.

17. Republic of South Africa, Review of Defence and Armaments Production: Period 1960 to 1970, pp 5, 9 .

18. T.R.H. Davenport: 1991. South Africa: A Modern History, 4th ed (MacMillan: Basingstoke and London), pp 356-58, 363-67, 388; Republic of South Africa. 1973. White Paper on Defence and Armament Production, 1973, pp 1-5; Republic of South Africa, White Paper on Defence and Armaments Supply, 1982, p 1.

19. T.R.H. Davenport, South Africa: A Modern History, pp 364-67, 388. 
the words of the White Paper on Defence 'terrorists [were] active in Angola, Moçambique and along the Rhodesian border' and their 'training, organisation and armament [were] improving appreciably'. ${ }^{20}$ During 1966/1967 a number of guerrillas from the South West African People's Organization (SWAPO), resisting South African rule in South West Africa (SWA)/Namibia, infiltrated that territory and clashed with the South African Police in the Caprivi Strip. ${ }^{21}$ The early 1970s saw a significant increase in guerrilla activities on the (SWA)/Namibia border and the South African Defence Force (SADF) stepped in to assume responsibility for counterinsurgency operations in that territory. ${ }^{22}$ The sudden collapse of the neighbouring Portuguese buffer states, Angola and Mozambique, in 1974/75, and Rhodesia in 1979 increased the pressure on the borders of South Africa and SWA/Namibia significantly, since it offered the liberation movements bases on South Africa's doorstep from where they could infiltrated the country ${ }^{23}$ 'for the purposes of terrorism, sabotage and subversion with a view to overthrowing the existing order. ${ }^{24}$

In his introduction to the 1973 White Paper on Defence, the Minister of Defence, P.W. Botha, stressed South Africa's willy-nilly involvement in the global power struggle, stating:

The RSA is part of the modern world, and as such, involuntarily involved in the prevailing international struggle for power. Furthermore, as a result of the relative check-mate... between the super powers in the sphere of nuclear weapons, we find ourselves in a position of increasing strategic importance in that struggle. Like the rest of the Free World, the RSA is a target for international communism and its cohorts - leftist activists, exaggerated humanism, permissiveness, materialism and related ideologies. The RSA has been singled out as a special target for the byproducts of their ideologies, such as black racialism, exaggerated individual freedom, one-man-one-vote, and a host of other slogans... Geographically the RSA is a part of the Third World: in the military and

20. Republic of South Africa, Review of Defence and Armaments Production: Period 1960 to 1970, p 26

21. Republic of South Africa. 1969. White Paper on Defence and Armament Production, 1969, p 5; T.R.H. Davenport, South Africa: A Modern History, p 388.

22. Republic of South Africa, White Paper on Defence and Armament Production, 1973, pp 15; Republic of South Africa, White Paper on Defence and Armament Production, 1975, pp 4-7; T.R.H. Davenport, South Africa: A Modern History, pp 456, 459, 473-74.

23. Republic of South Africa, White Paper on Defence and Armament Production, 1975, p 7; Republic of South Africa, White Paper on Defence and Armaments Supply, 1982, pp 2-3.

24. Republic of South Africa, White Paper on Defence and Armament Production, 1975, p 7. 
cultural spheres it is a captive ally of the West, and ideologically a direct obstacle in the path of communism. ${ }^{25}$

In terms of the internal black liberation struggle Botha warned that South Africa faced 'an acknowledged concept in communist strategic options', namely a 'protracted war of low intensity in which the enemy retains the initiative, keeps the target country in constant suspense and tries to break it by undermining and sapping its resistance'. A 'basic strategy' in this process was 'promoting insurgency from neighbouring countries' ${ }^{26}$ The Soviet Union, in view of the South African strategists, deliberately pinned the SADF down in a protracted 'terrorist war' on the SWA/Namibian border to promote and support 'terrorist activities' within South Africa. ${ }^{27}$

This threat perception, in the mid-1970s, ushered in the era of 'total onslaught' and 'total strategy' in South Africa's strategic thinking, which was not really a new concept, since the 1969 White Paper on Defence and Armament Production already stated that 'the unconventional method of warfare can entail the involvement of an entire country in such a conflict'. ${ }^{28}$ In the 1973 White Paper Botha emphasized that it was of vital importance for South Africa to closely coordinate and integrate 'internal policy, foreign policy and defence policy... in the present international climate which is typified by total strategy... our defence is not a matter for the Defence Force only, but also for each department and citizen. ${ }^{29}$

The 1975 White Paper took the idea of 'total onslaught' and 'total strategy' further. It stressed the 'intensifying hostile actions by anti-movements and extremist ideological elements' and stated:

The fact that the moving forces behind this enmity - wittingly or unwittingly - virtually always derives from ideological objectives or inspirations, and that the leaders are extremists, involves the danger of desperate actions. The ideological and extremist psychology rejects evolution and reform and views any progress in this respect as a threat to its cherished goal of revolution. We can therefore expect from these

25. P.W. Botha. 1973. Preface. In Republic of South Africa. White Paper on Defence and Armament Production, 1973, p 1.

26. P.W. Botha. 1973. Preface. In Republic of South Africa. White Paper on Defence and Armament Production, 1973, p 2.

Republic of South Africa, White Paper on Defence and Armaments Supply, 1982, p 1.

Republic of South Africa, White Paper on Defence and Armament Production, 1969, p 5.

P.W. Botha. 1973. Preface. In Republic of South Africa. White Paper on Defence and

Armament Production, 1973, p 1. 
sources ever more intense and more acrimonious attacks in every conceivable field - from sport to force of arms. ${ }^{30}$

From this perspective it was not Government policy 'to base our national defence on military capabilities alone (or even primarily)... [and] military means (consequently) do not play the major role in our total defence policy. ${ }^{31}$ The 1977 White Paper stated that South Africa was faced with a total, multidimensional onslaught on the military, psychological, economical, political, sociological, technological, diplomatic, ideological, cultural, religious and other fronts. Government thus had to formulate a total national strategy involving all government departments and utilising all national resources - including the private sector and every citizen, black and white - on an integrated basis to counter the onslaught on every front. $^{32}$

The simmering internal dissatisfaction erupted abruptly in a student uprising in Soweto in June 1976, firstly against inferior black education, but generally as a result of a broad spectrum of socio-political and economic grievances. The unrest spread rapidly throughout the country and sparked off a sustained situation of unrest and violence that continued until 1980. Jerked into action by the student uprisings, the ANC and PAC revitalised their armed struggle, gaining many recruits as a result of the momentum created by the student uprisings. ${ }^{33}$

The Soviet Union, according to South Africa's threat perception, gave increasing military support to Angola and Mozambique to ensure their continued support of 'terrorism' in SWA/Namibia and South Africa. In addition to the perpetuated presence of Cubans, Soviet and East German military personnel now became more and more involved in direct support of Angola and Mozambique's armed forces and the training of SWAPO and ANC guerrillas. At the same time the Soviet Union supplied these countries generously with weapons, including tanks and aircraft. The air space of these two countries also became increasingly inaccessible to the SA Air Force as the Soviet Union systematically improved their air defence systems, supplying advanced ground-to-air missiles and supporting radar systems. ${ }^{34}$ The latter was, of course, almost a mirror image of the situation in the Middle East

\footnotetext{
Republic of South Africa, White Paper on Defence and Armament Production, 1975, p 5. Republic of South Africa, White Paper on Defence and Armament Production, 1975, p 4.

Republic of South Africa. 1977. White Paper on Defence, 1977, pp 4-5.

T.R.H. Davenport, South Africa: A Modern History, pp 388-93.

Republic of South Africa, White Paper on Defence and Armaments Supply, 1982, p 2; Republic of South Africa. 1986. White Paper on Defence and Armaments Supply, 1986, p 12.
} 
during the 1970s when the Soviet Union put a virtually impenetrable air defence system over Egypt's border with Israel. ${ }^{35}$

By the mid-1980s, SADF estimates placed 'approximately 40000 troops from surrogate countries' in Angola, with ten to fifteen Soviet officers 'attached as command elements'. ${ }^{36}$ The influx of sophisticated military equipment, especially into Angola, continued unabated, escalating the conventional threat significantly. South Africa in fact became involved in large-scale conventional operations against Soviet-led forces in Angola in the 1980s in support of Unita. At the same time the Soviet Union intensified its multi-dimensional 'total onslaught' against South Africa's political, economic, social, security and psychological power base through the Third World, the UN, the OAU, the World Council of Churches and other international organisations. These organisations were also used to exert pressure on South Africa to refrain from cross-border strikes against guerrilla bases in neighbouring countries, a method often used by South Africa to pre-empt and disrupt its enemies. The OAU became 'one of the most important forums by means of which the activities of the African states... [were] co-ordinated and directed... [and] a channel for providing funds for the revolutionary onslaught ${ }^{17}$ against the RSA. Zambia, Botswana, Zimbabwe and Mozambique were especially 'increasingly prepared to allow the ANC... to commit deeds of terror in the RSA through, and from, their territories.'. ${ }^{38}$

A new wave of internal unrest, violence, civil disobedience and consumer boycotts, supported by 'terrorist activities' from across its borders, hit South Africa in September 1984, with a view to making the country 'ungovernable' and the politico-constitutional reforms of the Apartheid government 'unworkable'. Consequently, the SA Army was deployed in support of the South African Police from October 1984 to curb the unrest. This new cycle of unrest was accompanied by extensive international media campaigns to discredit the South African Government and create the perception that government had lost control of the internal situation. From 1984 to 1986 foreign radio propaganda against South Africa, especially conducted from Ethiopia, Zimbabwe, Angola, Tanzania, Mozambique, Lesotho, Nigeria, the Soviet Union and Germany, but also from the USA, Great Britain, France and the Netherlands, rose by $50 \%{ }^{39}$

35. Herzog, C. 1985. The Arab-Israeli Wars: War and Peace in the Middle East from the War of Independence to Lebanon, 2nd ed. ( Steimatsky, Tel Aviv), pp 227, 307-308. Republic of South Africa, White Paper on Defence and Armaments Supply, 1986, p 12. Republic of South Africa, White Paper on Defence and Armaments Supply, 1986, p 12. Republic of South Africa, White Paper on Defence and Armaments Supply, 1986, p 12. Republic of South Africa, White Paper on Defence and Armaments Supply, 1986, pp 13-5. 


\section{The Military Academy's Response To The Revolutionary Onslaught}

The threat perception that emerged from 1960 onwards, both externally and internally, clearly required the Military Academy to equip young officers with a broad understanding of warfare, especially revolutionary and counterrevolutionary warfare, within the context (both technologically and socio-politically) of the Cold War. But the Academy, relocated to Saldanha during the mid-50s where it became a combined services Academy under the auspices of the University of Stellenbosch, failed to meet this requirement. The new academic dispensation made provision for three BMil degree courses, namely Human, Natural and Commercial Sciences. The BMil course in the Natural Sciences offered only one (partially) 'human sciences' subject, namely Geography. The BMil course in the Human Sciences included three 'natural sciences' subjects, namely Special Mathematics, Aeronautical Science and Nautical Science ('Sea Navigation'). Political Science and Public Administration were (though not from the start) included as compulsory subjects in the BMil in Commercial Sciences. Military History, widely regarded as the cornerstone of military education, was a compulsory subject in the BMil in the Human Sciences only. $^{40}$

With Military History absent from the BMil courses in both the Natural Sciences and the Commercial Sciences, and Political Science not offered in the BMil course in the Natural Sciences, the degree courses of the Military Academy had lost the common professional base it had in Pretoria. Not all cadets were thus prepared for the socio-political milieu in which they were to operate, a significant failure with a view to the nature of counterrevolutionary warfare. The Dean and Commanding Officer of the Military Academy, Col PJ.G. de Vos, spotted the gap and pointed out that this was contrary to the practice abroad. He made a strong plea for the inclusion of Political Science in the curricula for the BMil in the Natural Sciences and, in addition, appealed to Defence Headquarters to introduce Ethnology as a subject at the Military Academy. Both recommendations were rejected, ${ }^{41}$ indicating that Defence Headquarters had not yet bought the necessity of a broad, liberal education for all officers, nor realised the crucial role the Academy could play in equipping officers with a broad frame of reference to address the intellectual challenges associated with the threat perception.

40. D. [G.E.] Visser: 2002. Marrying Sparta and Athens: The South African Military Academy and task-orientated junior officer development in peace and war. Journal for Contemporary History, Vol 27, No 3, December, pp 190-91.

41. G.E. Visser. 2000. Die Geskiedenis van die Suid-Afrikaanse Militêre Akademie, 1950 - 1990

[The History of the South African Military Academy, 1950 - 1990] (Doctoral dissertation published as Supplementa ad Scientia Militaria I), pp 271-73. 
In 1967, the Chief of the South African Defence Force, Gen. R.C. Hiemstra, complained that there was 'too much emphasis... on academic education, with the result that the Academy-product... [was] not equal to his task as young officer, especially with regard to the practical demands of leadership and task performance at the lowest level". ${ }^{42}$ This sparked off two extensive investigations into the role and function of the Military Academy in 1967 (Hartzenberg Committee ${ }^{43}$ ) and 1968 (Malan Committee ${ }^{44}$ ). The Hartzenberg and Malan investigations, which studied the training and educational systems of various military institutions abroad, emphasised that an officer should be an intelligent, well-balanced, educated, patriotic and religious person of high integrity and moral values, able to fulfil leadership roles both as a military professional and in civil society. His training and education should be aimed at his deployment both as officer and citizen, at equipping him professionally for modern warfare, including low-intensity revolutionary and counterrevolutionary warfare, and at enabling him to understand society and his role in it. ${ }^{45}$ Both the international principles of junior officer education and the national threat perception thus confirmed the need for a broad, liberal education, based in the social sciences, for all officers.

In view of these findings, Professor G. van N. Viljoen, Rector of the Rand Afrikaans University, was consulted on the future composition of the BMil curricula. He stressed that the BMil curricula should have a common professional base, which, in his view had to be 'Military Science'. This he defined broadly as 'a continuous, scientifically based and well co-ordinated study of the entire military situation $^{\prime 46}$. His plea was thus clearly for a number of compulsory core subjects, based in both the social and the natural sciences. Any BMil curriculum without such a common 'scientific pillar' would fail to achieve the desired results of officer

42. Mil Acad Archives, Reports, HWA/599/2/12/3, "Verslag van Komitee van Ondersoek insake Werwing, Keuring, Aanstelling en Opleiding van Staandemagoffisiere" [Report of Committee of Inquiry on the Recruiting, Selection, Appointment and Training of Permanent Force Officers] (hereafter: Hartzenberg Report, 13 February 1968, p 4 (author's translation).

43. See Mil Acad Archives, Reports, HWA/599/2/12/3, "Verslag van Komitee van Ondersoek insake Werwing, Keuring, Aanstelling en Opleiding van Staandemagoffisiere" [Report of Committee of Inquiry on the Recruiting, Selection, Appointment and Training of Permanent Force Officers], 13 February 1968.

44. See SANDFA, MVB 164, "Verslag oor die Militêre Akademie Deel I" [Report on the Military Academy], 28 February 1969.

45. Hartzenberg Report, pp 7-10, 116-18, SANDFA, MVB 164, "Verslag oor die Militêre Akademie Deel I" [Report on the Military Academy] (hereafter: Malan Report) 28 February 1969 , pp 8-11, 29.

46. SANDFA, CSP (Classified) 10, HWA599/2/12/3 Vol 1, G. van N. Viljoen - C.H. Hartzenberg, 15 December 1967 (author's translation). 
education, namely to enable officers to think critically and independently about their profession and apply their knowledge effectively in any given situation. ${ }^{47}$

The recommendations of the Hartzenberg and Malan Committees led to the introduction of a new training and education system at the Military Academy in 1970, based on a threefold concept of formative officer development comprising general, scientific and military education. ${ }^{48}$ The military authorities took heed of Prof Viljoen's plea for a core curriculum and made Military History and Political Science compulsory for all students at first-year level, regardless of their direction of study. The rest of their subjects depended on the student's study direction, the need of his service or corps and his personal choice. ${ }^{49}$ The Hartzenberg Committee recommended the inclusion of Ethnology and Psychology in the BMil curricula, ${ }^{50}$ while the Malan Committee wanted to add Sociology. ${ }^{51}$ All these subjects were extremely relevant and useful in equipping young officers for counterrevolutionary warfare, inter alia in the 'winning of hearts and minds' programmes. In the end Defence Headquarters included none of these subjects in the new curricula, probably because of the cost implications, and thus failed to empower the Academy to realise its full potential in preparing young officers for the perceived threat perception. However, with Military History and Political Science as compulsory subjects in all study directions, the BMil had once again at least some common base that orientated prospective officers in the socio-political milieu in which they would be expected to operate. Furthermore, all prospective officers of the SADF henceforth spent at least six months at the Academy if they could or would not follow the entire degree course. $^{52}$

The escalation, from 1976, of the South African Defence Force's involvement in the so-called "Bush War" on the borders of South West Africa/Namibia had a profound negative influence on officer education at the Military Academy. To satisfy the increasing demand for junior officers, Defence Headquarters decided that candidate officers should be "task qualified" within their respective service and undergo some in-service training, before receiving their commissions or becoming eligible for admission to the Military Academy. From 1976 the responsibility for formative training was thus retransferred to the arms of service. But, more significantly, the Military Academy was taken out of the loop of

47. SANDFA, CSP (Classified) 10, HWA599/2/12/3 Vol 1, G. van N. Viljoen - C.H. Hartzenberg, 15 December 1967.

D. [G.E.] Visser, Marrying Sparta and Athens, p 192; Malan Report, pp 8 - 11, 29.

Malan Report, pp 39-46, 52-3.

Hartzenberg Report, pp 42-3, 125-26, Appendix A.

Malan Report, pp 39-46, 52-3.

D. [G.E.] Visser, Marrying Sparta and Athens, p 192. 
officer development completely, since the degree course no longer formed part of the preparation of candidate officers for commissioning. ${ }^{53}$ Operational realities, specifically the shortage of human resources, thus caused the Defence Force to abandon tertiary military-academic education as an important component of preparing junior officers for the perceived threat perception and to rely on functional, 'task-orientated' training alone.

As a result of these developments tertiary education at the Military Academy became an optional extra for those who wished to embark upon that route. Instead of preparing candidate officers for commissioned appointment, the Academy now became a de facto military university offering university education to commissioned officers, some already holding the rank of major. ${ }^{54}$ At the height of the former South African government's counterinsurgency war most young officers were consequently thrown into the operational environment before they had the benefit of an academic education to prepare them for that environment at an intellectual level. Furthermore, those who did end up at the Academy, once more studied diverging BMil degree courses without any common, professional base (core curriculum), since Military History and Political Science were no longer compulsory subjects. ${ }^{55}$ In general the academic offerings of the Military Academy were therefore neither relevant to the threat perception, nor conducive of a broad, liberal education as fundamental principle of junior officer development.

What Lieutenant General R.J. Evraire of the Canadian Forces observed with regard to his country's military in 1988, was now also true about the South African Defence Force: 'higher education was not conceived... as a way to develop the minds of officers; rather it was a task-oriented function to acquire a skill for which there was an obvious and immediate need for a few, mostly in technical areas. ${ }^{56}$ Adapting to this scenario, the Military Academy worked at making its academic offerings relevant to task-orientated officer development. Through a process of extensive consultation with the services the Academy brought its curricula and course contents once more into alignment with the articulated needs of the Defence Force, introducing new subjects, such as Business Psychology (Mil) (later Industrial

53. Military Academy Archives, 'Verslag deur Komitee van ondersoek met betrekking tot Jongoffisiersopleiding te Militêre Akademie Saldanha' [Report by the Committee of Inquiry on Young Officer Development at the Military Academy, Saldanha (hereafter: Van der Westhuizen Report), 31 January 1975, pp 9-10, 31, 55.

54. D. [G.E.] Visser, Marrying Sparta and Athens, p 195.

55. Universiteit van Stellenbosch. 1977. Jaarboek 1977 Deel 13: Fakulteit Krygskunde; Universiteit van Stellenbosch. 1978-85. Jaarboek 1977-1985 Deel 14: Fakulteit Krygskunde.

56. R.G. Haycock, The Labours of Athena and the Muses, $\mathrm{p} 12$. 
Psychology (Mil)) and Computer Information Systems (Mil) in the 1980s to meet previously uncatered for needs. ${ }^{57}$

Besides the lack of an appropriate core curriculum, the number of officers passing through the Academy also impacted negatively on the institution's relevance to the threat perception. On the one hand cost factors prohibited a significant increase in the Academy's student body, and on the other Defence Headquarters were never quite clear about the percentage of the officers' corps that had to obtain the BMil degree. The Malan Committee (1968) indicated a total of $30 \%$ for the army and $20 \%$ each for the air force and the navy. These figures were raised in 1976 to a desired minimum of $25 \%$ of the total officers' corps, which implied an annual intake of 106 students. Thereafter the intention seems to have been to route as many officers as operational requirements, the budget and available facilities allowed, through the Academy, without setting a specific percentage. The desired annual intake was raised to 175 in 1982, and in May 1985, Defence Headquarters decided to increase the total student body to 235 by 1990 and 325 by 1995 . However, none of these enrolment targets were ever realised in practice. The average annual intake only rose from 45 in 1961 to approximately 68 by 1985 , resulting in a total undergraduate student body of about 200 per year. By 1990 the average, annual first-year enrolment had climbed only to 89 , still way off the official target of 235 per year. This perpetuated under-enrolment resulted from a chronic lack of suitable applications, mostly due to the operational requirements of the services and the fact that candidates who followed the Academy-route, fell behind their peers career wise, especially in terms of rank promotion. ${ }^{58}$ This was of course not unique to South Africa. In the Canadian forces, Haycock observes, 'seeking higher education became a career punitive... and consequently many did not seek it at all' ${ }^{59}$ It would certainly not be too difficult to find similar examples in other defence forces also.

\section{Post-Cold War And Post-Apartheid Developments}

The collapse of the Soviet Union in the late 1980's and the consequent termination of the Cold War changed South Africa's security situation completely. The SADF and Cuban forces withdrew from Namibia and Angola, and Namibia became a sovereign state in March 1990. Meanwhile, in February 1990, the National Party Government unbanned the ANC, PAC, SACP and other organisations associated with the liberation struggle in South Africa and embarked

57. D. [G.E.] Visser, Marrying Sparta and Athens, pp 195-196.

58. G.E. Visser, Die Geskiedenis van die Suid-Afrikanse Militêre Akademie, 1950 - 1990, pp 174-5, 248-56, 400, 428-9.

59. R.G. Haycock, The Labours of Athena and the Muses, $\mathrm{p} 12$. 
upon an all-party political negotiation process that culminated in a new, democratic political dispensation in South Africa on 27 April 1994. With these developments, both the internal and external threat linked with communist expansion for so long, disappeared. As was the case immediately after the Second World War, South Africa found itself without a discernible military threat once again.

With the evaporation of the military threat during the final years of the old dispensation, the Military Academy by and large continued to respond to the functional needs of the former SADF. The increasing focus on applying business principles to the military, particularly the emphasis on management rather than traditional military leadership, led to the renaming of the Commercial Sciences to Management Sciences and the conversion of Business Economics (Mil) to Military Management in 1991. At the same time, however, General J.J. Geldenhuys, then Chief of the former SADF, emphasised the need for a core subject to form the basis of 'military science' and thus of all BMil degree courses. He suggested that Military History should play that role, but his expectations with regard to the subject content was apparently of such a nature that it was decided to introduce a new, multidisciplinary subject, Military Strategy, as a compulsory subject for all degree courses instead. ${ }^{60}$ Comprising elements of, inter alia, political science, military history and military sociology, ${ }^{61}$ the subject Military Strategy revived the concept of a core curriculum to provide all Academy graduates, regardless of their study direction, with a broad understanding of warfare and the profession of arms. Though Military Strategy could hardly provide a comprehensive foundation for military science on its own, its institution as a compulsory subject was a step in the right direction, since it introduced students to a variety of possible threat scenarios.

South Africa's transition to democracy on 27 April 1994 naturally brought about a complete transformation of the country's defence function as well. This included first and foremost the institution of civil control over the military and the integration of the former statutory and non-statutory forces ${ }^{62}$ into the new SANDF. It also encompassed the equally important issues of formulating a new, appropriate defence policy, restructuring and rightsizing the SANDF and implementing equal opportunity policies and affirmative action to make the SANDF representative of

60. G.E. Visser, Die Geskiedenis van die Suid-Afrikaanse Militêre Akademie, 1950 - 1990, pp 494-7.

61. Universiteit van Stellenbosch. 1991. Jaarboek 1991-92 Deel 14: Fakulteit Krygskunde, pp 20-1.

62. These were the former SADF, the defence forces of the former independent black states of Transkei, Boputhatswana, Venda and Ciskei, the guerrilla forces of the ANC (MK) and the PAC (APLA) and the KwaZulu Self-Protection Forces of the Inkatha Freedom Party. 
South Africa's demographic profile. ${ }^{63}$ These and other aspects of the transformation of South Africa's defence found expression in the White Paper on Defence published in May 1996 and the subsequent Defence Review released in April 1998. ${ }^{64}$ The White Paper asserted that 'South Africa... is not confronted by an immediate conventional threat and does not anticipate external military aggression in the short to medium-term'. ${ }^{65}$ This post-apartheid threat perception set the stage for the $21^{\text {st }}$ century and will be discussed under the next heading, together with the Military Academy's response to it.

The absence of a direct military threat provided 'considerable space to rationalise, redesign and rightsize ${ }^{, 66}$ the SANDF, which had a positive impact on the enrolment of students at the Military Academy. The curtailment of the Defence Force's operational deployment created more time for officer development and reopened the opportunity to include the Military Academy in the loop once more. At the same time, the complex and uncertain post-Cold War military environment impressed upon the military authorities the necessity to raise the educational level of the officers' corps. At the national level the advent of the new political dispensation certainly sensitised military leaders for the value of contextualised tertiary education in reconciling cultural differences in the longer term integration of the statutory and non-statutory military forces into a new, professional, representative SANDF. ${ }^{67}$

The process of increasing the student body at the Academy and making it representative of the South African population commenced before 1994. The former SADF already put plans in place in 1990 to increase the total number of students at the Academy from approximately 200 to 450 by 1999 . At the same time it was realised that, with a view to the coming of a new, democratic South Africa, the issue was not only how many students were admitted to the Academy, but also who those students were. For almost three decades the Academy had been an exclusively white, male institution. Female (three) and so-called "coloured" (one) students were only admitted to the Military Academy as late as 1978 and 1979 respectively. The admittance of female students, however, was suspended the very next year due to lack of suitable accommodation, while candidates from the "other population

63. L. Le Roux. 2003. The South African National Defence Force and its involvement in the Defence Review process. In R. Williams, G. Cawthra and D. Abrahams (eds). Ourselves to Know: Civil-Military Relations and Defence Transformation in Southern Africa (Institute for Security Studies, Pretoria), pp 153-4.

64. See Department of Defence. 1998. Defence in Democracy: South African White Paper on Defence as Approved by Parliament, May 1996 [and] South African Defence Review as Approved by Parliament, April 1998. (Department of Defence, Pretoria).

65. White Paper on Defence 1996, p 12.

66. White Paper on Defence 1996, p 13.

67. D. [G.E.] Visser, Marrying Sparta and Athens, pp 195-96. 
groups" were never forthcoming in significant numbers. The dawning of the new political landscape brought the first concerted effort to make the student body more representative of the South African population. Female students were readmitted in 1991, and every effort was made to recruit more students from the Indian, black and so-called "coloured" communities. The year 1991 saw the admittance of the firstever black students. ${ }^{68}$

Though efforts to achieve the ideals of greater numbers and a representative student body were stepped up significantly from 1994, neither had been realised by the turn of the century. After reaching an all-time high of 273 students in 1998, it dropped to 235 in 1999 and to 187 in 2000 due to a lack of suitable candidates. By 2000 historically-disadvantaged ethnic groups still comprised only a third of the student body, while female students also formed a third of the total. ${ }^{69}$ These facts seem to suggest that the military was not a preferred career path for young people, amongst other things perhaps because the new political dispensation opened up many other, more attractive, career opportunities for historically-disadvantaged groups.

\section{Meeting The Challenges Of The $21^{\text {st }}$ Century}

When the world famous air theorist and military writer, Air Vice-Marshal R.A. Mason, addressed the concluding session of the United States Air Force Academy's 17th Military History Symposium on 22 November $1996,{ }^{70}$ he tabulated 'ten features likely to influence the security environment' of the 21 st Century from the US Air Force's perspective, namely: ${ }^{71}$

- No direct threat to the national integrity of the United States;

- A need for constant vigilance against the emergence of any future threat;

- Continued concern for regional stability and U.S. interests worldwide;

- Commitments will frequently be unpredictable;

- Responsibilities will include "peacekeeping" and humanitarian operations;

68. G.E. Visser and I. Van der Waag: 2000. Military Academy - 50 years of officer education in SA. SALUT, Vol 7, No 4, April, p 54.

69. Mil Acad Archives, Military Academy Annual Report: Appendix B: Annual Report of the Faculty of Military Science, 1999; Mil Acad Archives, Military Academy Annual Report: Appendix B: Annual Report of the Faculty of Military Science, 2000.

70. R.A. Mason. 1998. The Challenge of the Twenty-first Century: Balancing General Education, Military Training, and Professional Studies. In E.V. Converse III (ed). Forging the Sword: Selecting, Educating, and Training Cadets and Junior Officers in the Modern World (Imprint Publications, Chicago).

71. R.A. Mason. 1998. The Challenge of the Twenty-first Century, p 391. 
- New dangers from terrorism and international crime, particularly narcotics;

- An extended period of dwindling resources allocated to defence;

- Most military operations will be exposed to international media, with an instant impact on public opinions and government policy;

- The impact of technology; and

- An unchallenged aerospace world supremacy of the US Air Force.

National and regional circumstances will certainly put its own stamp on Mason's list of 21st century security features, but they are in essence applicable universally. The SANDF's likely deployment in the 21st century will probably be in connection with secondary, non-combat functions relating to internal law and order, illegal immigration, cross-border trafficking in drugs, stolen goods and small arms, civil disasters and regional peace-support operations. ${ }^{72}$ Referring to the aforementioned absence of a direct military threat against South African, the 1996 White Paper observes that 'the vast majority of (international) conflicts are taking place within rather than between, states' and that such conflicts 'arise from internal ethnic, religious and other divisions'. The White Paper stresses that 'such conflicts are increasingly regarded as regional and international concerns ${ }^{, 73}$ and that South Africa's security is therefore intimately intertwined with that of Sub-Saharan Africa and in particular Southern Africa. South Africa will consequently 'encourage the development of a multi-lateral 'common security' approach in Southern Africa'. ${ }^{74}$

Plagued by poverty, underdevelopment, internal conflict, environmental degradation and disease, much of Sub-Saharan Africa remains volatile and conflict has indeed escalated in the region since the end of the Cold War. International borders do not contain conflict arising from these phenomena and there is always the possibility that regional conflicts could spill over to South Africa. ${ }^{75}$ Constant vigilance against the emergence of direct military threats is therefore not negotiable and the primary function of the SANDF will always be to defend South Africa against external military aggression. From a common security perspective the 1996 White Paper anticipates that 'situations may arise in southern Africa where inter or

72. Defence Review 1998, p 18; L.S. Mollo. 2003. Exemplary leadership and exemplary teams: Unleashing future defence leadership. Scientia Militaria, Vol 31, No 1, p 117; M. Lekota. 2003. Opening Speech at Meeting of SADC Defence Ministers, 3 July. African Armed Forces, July, p 20.

73. White Paper on Defence 1996, $\mathrm{p} 12$.

74. White Paper on Defence 1996, p 13.

75. M. Lekota. 2003. Opening Speech at Meeting of SADC Defence Ministers, 3 July. African Armed Forces, July, p 20. 
intra-state conflict poses a threat to peace and stability in the region as a whole... [and] it may become necessary to deploy the SANDF in multi-national peace support operations' on the subcontinent. ${ }^{76}$ After all, the post-Cold War international community is displaying increasing ambivalence towards conflict resolution in Africa and has made it clear that African states will be required to take care of their own peacekeeping needs. ${ }^{77}$ To that end South Africa has already demonstrated her commitment to take up the burden by deploying the SANDF to Lesotho, Burundi and the DRC on peace support missions.

Regional security, peace and stability also take a high priority on South Africa's defence agenda, with a view to the Republic's perceived leadership role in the African Renaissance. As E.A. Thorne points out:

As is plain for all to see, progress towards the... African Renaissance will often be halting and there will be reverses. It is in such circumstances that the more democratically advanced African states may well have to militarily intervene or dispatch peacekeepers and peacemakers to restore order or to create the conditions for a new beginning. ${ }^{78}$

South Africa is widely regarded as 'the one state able to ensure effective peacekeeping on the African continent ${ }^{79}$ and is consequently expected to play a leading role in that regard. Much of this is, however, expected to take place within collective structures. At a meeting in the Ethiopian capital, Addis Ababa, in May 2003 the African Chiefs of Staff laid the foundation for the creation of an African Standby Force (ASF) to fulfil this regional policing role. ${ }^{80}$ Briefing Parliament on these developments in June 2003, South African Defence Minister, Mosiuoa Lekota, said that agreement had already been reached on issues such as

doctrine and posture, shifts in the nature of peacekeeping operations, interoperability of forces, common standards of training, equipment and logistics, standard procurement regimes for commonly identified appropriate equipment needs, the establishment of command structures

76. White Paper on Defence 1996, p 15.

77. T. Neethling. 1999. Participation in Sub-Saharan Peace Support Operations. In L. du Plessis and M. Hough (eds). Protecting Sub-Saharan Africa: The Military Challenge (HSRC Publishers, Pretoria), pp 183-4.

78. E.A. Thorne. 2003. The African Standby Force Takes Shape: An Observation of Needs and Necessary Actions. African Armed Forces, July, p 26.

79. T. Neethling, The South African military and peacekeeping, $\mathrm{p} 95$.

80. Defence Review 1998, pp 12-5; E.A. Thorne. 2003. The African Standby Force Takes Shape, p 27. 
and so on... The SANDF will have to align itself more coherently with these new developments. ${ }^{81}$

It is very clear from the above-mentioned scenario that SANDF officers will be operating in a very complex socio-political milieu in the 21 st century, both nationally and regionally. Mason's observation on the challenges facing US Air Force officers in the 21 st Century is equally true of South African officers:

Junior officers will be exposed suddenly and frequently to widely differing cultures and regions. They may carry much greater personal responsibility; to the point of individually enhancing or damaging national credibility because of the constant interaction between operations, media coverage, and public and international opinion. ${ }^{82}$

It is thus imperative that SANDF officers should know and understand the societies (foreign and domestic) in which they operate or may be required to operate, their role in those societies and the possible repercussions of their actions. The Canadian Defence Force discovered the need for such knowledge the hard way a decade ago. On 16 March 1993, while on a peacekeeping mission in Somalia, a master corporal and a private soldier of the Canadian Airborne Regiment brutally beat a detained Somalian teenager to death. The official Canadian enquiry 'stipulated leadership failure as the overriding factor underlying the conduct associated with the incident'. ${ }^{83}$ The Commission of Enquiry investigating this incident found that 'the problems went far deeper than the events in Somalia, and they involved the fundamental issues of shortcomings in military leadership and ethics, and thereby education. ${ }^{.84}$ Investigations into Canadian officer education revealed that in sharp contrast to the US forces who normally required a master's degree for promotion beyond the rank of Major, only about $50 \%$ of Canadian officers had a university education at all and that:

what focus on higher education has existed, is primarily in the technical fields, especially those with immediate, practical applications. There has

81. M. Lekota, quoted in E.A. Thorne. 2003. The African Standby Force Takes Shape: An Observation of Needs and Necessary Actions. African Armed Forces, July, p 27.

82. R.A. Mason, The Challenge of the Twenty-first Century, $p 391$.

83. G. Shorey. 2001. Bystander Non-Intervention and the Somalia Incident. Canadian Military Journal, Vol 3, No 4, Winter 2000 - 2001, p 19.

84. R.G. Haycock. 2001. The Labours of Athena and the Muses: Historical and Contemporary Aspects of Canadian Military Education. Canadian Military Journal, Vol 2, No 2, Summer 2001, p 6. 
been little apparent official emphasis on liberal education or in the humanities and social sciences. ${ }^{85}$

Retired Canadian General Ramsey Withers in 1998 concluded that:

Officer trainees need a fairly comprehensive introduction to the profession of arms and its component parts. In post industrial, liberal democracies this introduction includes extensive studies of the humanities and solid grounding in the sciences. In addition, the study of military theory and military history is mandatory. ${ }^{86}$

The end result of the investigations into Canadian officer education was that the Canadian Defence Minister made a university degree compulsory for all officers in $1997 .{ }^{87}$ At the same time a core programme, common to all cadets at the Royal Military College (RMC), Kingston, Canada, had to be introduced:

The core was to include courses in military history, civics, military law, Canadian military history, military theory and strategy, international relations, leadership and ethics, information technology, and emerging technologies. Mathematics and science subjects were to be well represented. The traditional degrees would continue in Engineering, Science and the Arts, but the core courses would constitute $30 \%$ of the courses taken in any degree pattern by all cadets. ${ }^{88}$

The idea of a broad core curriculum is neither unique to the RMC in Canada, nor new. To state but one example, all US service academies have had core curricula based in both the natural and human or social sciences throughout their existence. In the case of West Point, all cadets must complete a core curriculum of 31 courses, regardless of their academic majors. The natural sciences component comprises four semesters of mathematics, two of physics, two of chemistry, one of terrain analysis, one of computer science and five from one of seven engineering sequences. The human and social sciences component comprises four semesters of history (including American, world and military history), three of social sciences, three of English, two of behavioural sciences, one of philosophy, two of a foreign language, and one of constitutional law. All of these are aimed at ensuring that US

85. R.G. Haycock, The Labours of Athena and the Muses, pp 7-8.

86. R.G. Haycock, The Labours of Athena and the Muses, $\mathrm{p} 8$.

87. R.G. Haycock, The Labours of Athena and the Muses, p 14.

88. R.G. Haycock, The Labours of Athena and the Muses, p 16. 
officers are able to operate in the complex and rapidly changing technological and socio-political environments of the contemporary world. ${ }^{89}$

The question, against this background, is how relevant the current academic offerings of the Military Academy are to the 21st Century educational needs of the SANDF in terms of the national threat perception and the associated role scenario of the SANDF? The Military Academy has indeed effected a fundamental restructuring of its academic menu to meet the perceived future educational needs of the SANDF. In 2001, after consultation with representatives of the various services and branches of the Defence Force, the Academy replaced its traditional degree courses in the Human, Management (Commercial) and Natural Sciences with six outcomes-based academic programmes designed in accordance with the transformation of higher education in South Africa. These are:

- a Programme in Technology;

- a Programme Technology and Management;

- a Programme in War, Environment and Technology;

- a Programme in Organisational and Resource Management;

- a Programme in Human and Organisational Development; and

- a Programme in Security and Africa Studies.

The Programme in Technology, aimed at the development of military officers' technological knowledge and competence relating to their specific arm of service, retained a natural science focus with the exception of compulsory courses in System Management for the third years and English Studies (Mil), for the first years. The Programme in Technology and Management, geared towards the combat branch officer, combines subjects such as Physics (Mil), Nautical Science, Aeronautics and Military Geography with Military Management, Economics (Mil), Accountancy (Mil) and Industrial Psychology (Mil). The Programme in War, Environment and Technology, destined to orientate combat officers in and sensitise/prepare them for the technological, physical, strategic and historical environment in which the military operates, includes a more equal combination of natural and social science subjects such as Military History, Industrial Psychology (Mil) and Political Science (Mil). The Programme in Organisational and Resource Management caters chiefly for support branch officers who require skills and competencies in the broader

89. D.J. Kaufman. 2001. Military Undergraduate Security Education for the New Millennium. In J.M. Smit, et al. Educating International Security Practitioners: Preparing To Face the Demands of the 21st Century International Security Environment. (Strategic Studies Institue, U.S. Army War College: Carlisle), pp 11-12. 
managerial sciences, aimed at effective, efficient, economical and transparent use of the financial and other resources within their area of responsibility. The main subjects incorporated into this programme are Military Management, Public Development Management (Mil), Economics (Mil) and Management Accounting (Mil). ${ }^{90}$

Two programmes are based primarily in the social sciences. The Security and Africa Studies Programme is geared to sensitise both combat and support officers to the historical, political, strategic, socio-economic and physical/geographical milieu in which the military operates. The main subjects included in this programme are Military History, Military Strategy and Political Science (Mil). The Programme in Human and Organisational Development serves to equip officers with skills and competencies to function effectively in the fields of human and organisational development and has Industrial Psychology (Mil), Military Management and Public Development Management (Mil) as its core subjects. $^{91}$

As was the case with the former degree courses, these new, career-orientated programmes are 'tailor-made' for the more functional academic needs of the services and their various branches. The combination of subjects that students are permitted to follow in these programmes consequently depends first and foremost on their service and mustering, though personal preference also plays a small role. ${ }^{92}$ Though some of these programmes overlap in certain subjects, the two skills-based subjects, Computer Skills (Mil) and English Studies (Mil) ${ }^{93}$ are the only subjects shared by all these programmes. There is thus, contrary to the international trend, no core curriculum that equips all Academy students with the basic technological and, especially, the socio-political knowledge required to orientate them in the complex environment of the 21 st century, particularly with a view to their expected peace support role in Sub-Saharan Africa. Furthermore, the structuring of these programmes was handicapped to some extent by the fact that budgetary constraints ruled out the possibility of introducing a new subject such as Military Sociology,

90. University of Stellenbosch, Calendar 2003 Part 13: Faculty of Military Science, 2003: pp 6-9.

91. University of Stellenbosch, Calendar 2003 Part 13: Faculty of Military Science, 2003: pp 1011.

92. University of Stellenbosch, Calendar 2003 Part 13: Faculty of Military Science, 2003: pp 6-11, 31-38.

93. University of Stellenbosch, Calendar 2003 Part 13: Faculty of Military Science, 2003: pp 6-11. 
which could be extremely useful in helping officers to understand the nature of social change and how this impacts on the military profession. ${ }^{94}$

Besides the restructuring of academic programmes, the turn of the century also saw a renewed effort, mostly by the Military Academy itself, to route more officers and prospective officers through the Military Academy. This was not only to enhance the educational level of the officers' corps, but also to ensure the future of the Academy by making it 'indispensable' to the SANDF. A new bridging programme of six months duration, known as the Preparatory Certificate in Military Studies, was introduced in 2000 to offer an alternative admission route to candidates, especially those coming from a disadvantaged educational background, who had the required potential for higher education but did not comply with university prerequisites. In addition, this programme also offers candidates who do comply with the prerequisites, but are regarded as students at risk the opportunity to improve their learning skills before embarking on a degree programme. ${ }^{95}$

Following this innovative step, the Academy introduced a one year Certificate in Military Studies in the technology related programmes for the pupil pilots of the South African Air Force in 2001. ${ }^{96}$ The Certificate in Military Studies was subsequently extended to the other services when the SANDF decided in 2002 to route all its prospective officers through the Academy by means of a newly designed Military Skills Development System (MSDS). This system was introduced to serve as primary source of personnel supply to both the permanent and the reserve forces, offering a voluntary two year service contract to selected school-leavers. Those earmarked for commissioned appointments after their first year of training, follow the Certificate in Military Studies at the Academy during their second year. A number of those who pass the certificate programme may, according to the needs of the services, be selected for extended contracts in the regular forces, while the rest may be offered five-year contracts in the part-time forces. Unsuccessful candidates may be offered contracts as non-commissioned officers in either the regular of the part-time forces. A selected number of those candidates who are offered extended contracts in the regular forces may be allowed to carry on with degree programmes at the Academy in accordance with the needs of the services. ${ }^{97}$

94. L. Heinecken and G.E. Visser. 2003. The South African Military Academy: Social Science, but no Sociology. (Unpublished paper, International Biennial Conference of the InterUniversity Seminar on Armed Forces and Society, Chicago, USA, 24 - 26 October 2003).

95. Mil Acad Archives, Military Academy Annual Reports, 2000 - 2003.

96. Mil Acad Archives, Military Academy Annual Reports, 2000 - 2003.

97. Mil Acad Archives (current), MA/R/104/31/2/1, Acting Secretary for Defence - Minister of Defence, etc., 5 December 2003. 
In 2004 the Certificate in Military Studies displaced the Preparatory Certificate in Military Studies completely. The former coincides with the first year of the various degree programmes, but also includes a military development component. The academic component of the various certificate programmes differs from the first year of the corresponding degree programmes only in that it requires fewer credits than the latter.

In addition to these non-degree programmes, a distance education programme (e-learning) was introduced at the Academy with effect from 2003. This initiative took the Academy's degree programmes not only to officers who are unable to study at the Academy on a residential basis, but also to all other members of the Department of Defence (DoD), including non-commissioned officers, private soldiers, civilians and members of the part-time forces. Furthermore, steps have been taken for the introduction of an MPhil programme in Security Management to be linked with the Executive National Security Programme for senior officers at the SA National Defence College. ${ }^{98}$

These new developments have increased the student body of the Military Academy significantly. The current (2004) residential undergraduate students number only 136, but this number is augmented by 149 MSDS students, 55 distance education students and 60 postgraduate students (honours and master's level), bringing the total to $400 .{ }^{99}$ In terms of racial representivity, the residential, undergraduate student body almost meets the target of $64,68 \%$ blacks, $24,35 \%$ whites, $10,22 \%$ coloureds and $0,75 \%$ Indians set for the DoD as a whole in the 1998 Defence Review, ${ }^{100}$ as it comprises $56,84 \%$ blacks, $28,07 \%$ whites, $13,68 \%$ coloureds and $1,40 \%$ Indians. At postgraduate level the student body is still far off target as it consists of $21,51 \%$ blacks, $55,74 \%$ whites, $14,75 \%$ coloureds and no Indians. ${ }^{101}$ The undergraduate distance education students also fall short of the target as they comprise $41,51 \%$ blacks, $28,30 \%$ whites, $28,30 \%$ coloureds and $1,89 \%$ Indians. ${ }^{102}$ While the 1998 Defence Review sets no definite target for gender representivity, the student population of the Military Academy certainly does not reflect the fact that females form about $51 \%$ of South Africa's total population. The residential, undergraduate student body comprises $78,88 \%$ male and $21,12 \%$ female

98. Mil Acad Archives, Military Academy Annual Report, 2003.

99. Statistics supplied by Faculty Clerk, Faculty of Military Science, 6 September 2004; Statistics supplied by Distance Education Office, Faculty of Military Science, 7 September 2004. (Most of the postgraduate students are studying on a modular, non-residential, basis, while nineteen are serving as academic assistants at the Faculty of Military Science.)

100. Defence Review 1998, $\mathrm{p} 80$.

101. Statistics supplied by Chair: Military Academy Representivity Committee, 27 September 2004.

102. Statistics supplied by Distance Education Office, Faculty of Military Science, 30 September 2004. 
students, while $67,21 \%$ of the postgraduate students are male and $32,79 \%$ female. ${ }^{103}$ Amongst the undergraduate distance education students the male-female ratio is $79,25 \%$ to $20,75 \% .{ }^{104}$ Whatever shortcomings remain, the Academy has certainly made significant progress since the early 1990s towards exposing a greater percentage of officers to tertiary education and meeting representivity targets.

\section{Conclusion}

The threat perception of a nation is an important guideline for officer education, since it defines or anticipates the military and socio-political milieu in which its officers must be prepared to operate. The direction taken from the threat perception must, however, be set against the fundamental principles of officer education, such as providing officers with a broad professional frame of reference and sound analytical, decision-making skills imparted through a broad, liberal education. The national threat perception merely provides a particular focus within that sphere.

The South African Military Academy has historically by and large failed to satisfy the requirements of the national threat perception. Firstly, the military authorities, contrary to international trends, have never located tertiary education at the heart of officer development, with the result that only a small percentage of the officer's corps was routed through the Military Academy. Secondly, the Academy, for most of its existence, lacked an appropriate core curriculum, compulsory to all students, to prepare them for the milieu defined by the threat perception. Academy students followed diverging curricula defined by the functional needs of the services and individual preference. The exception was the $1950 \mathrm{~s}$ when all students had to take Military Science, comprising Military History, Military Law, Military Geography and Military Technology, and the 1970s when Military History and Political Science were compulsory for all students. However imperfect these core curricula may have been, they did provide a common perspective on the profession of arms and an understanding of the milieu in which South African officers were required to operate in terms of the national threat perception. At the height of the former SADF's counterinsurgency war there was no social sciences based core curriculum to prepare all Academy students for the complexities of revolutionary and counterrevolutionary warfare; that benefit was restricted to those few that followed the BMil course in the Human Sciences. The same situation prevailed at the birth of the SANDF in 1994, when there was no core curriculum to create an understanding of the new socio-political landscape and the societal forces at work in the integration and transformation of the SANDF.

103. Statistics supplied by Chair: Military Academy Representivity Committee, 27 September 2004.

104. Statistics Distance Education Office, Faculty of Military Science, 30 September 2004. 
The new academic programmes instituted at the Academy in 2001 perpetuated the shortcomings of the past. Most of these programmes still address the functional needs of the various services only. They do not fully meet the requirements of South Africa's current threat perception, neither it in terms of preparedness to meet a direct military threat that might materialise unexpectedly, nor in terms of the secondary, essentially non-combatant, functions of the SANDF associated with its role in regional peace and security. The SANDF's perceived role in the new millennium as guardian of South Africa's national integrity, protector of the new democracy and peace supporter on the African continent, demands an institutionalised knowledge of the dynamics of the socio-political milieu within which its officers operate, but also keep pace with advances in weapons technology. This necessitates a rethinking of the Military Academy's academic programmes to create a core curriculum for all officers that satisfies these needs. This might require spreading the BMil programmes over four years, as is the custom at several military institutions abroad.

Furthermore, there could be little doubt that the complex technological and socio-political operational milieu that the SANDF faces in the 21 st century makes university education imperative for all its future officers. Passing a portion of new officers through the Certificate in Military Studies by means of the MSDS is a useful short term tool, but a plan must be devised to route as many young officers as possible through the Military Academy's degree programmes and to educate the rest at civilian universities, as is the trend internationally. All this will put more pressure on the declining defence budget, but a meagre saving now, might well result in blood and agony later, especially when young officers are deployed on widely diverse peace support missions in the complex politico-military milieu on the African continent. 